\title{
Over-production and Characterization of the nif $A$ Gene Product of Klebsiella pneumoniae - the Transcriptional Activator of nif Gene Expression
}

\author{
By R. TULI† AND M. J. MERRICK* \\ AFRC Institute of Plant Science Research, Nitrogen Fixation Laboratory, University of Sussex, \\ Brighton BNI 9RQ, UK
}

(Received 14 September 1987)

The nifA gene of Klebsiella pneumoniae, which encodes the transcriptional activator of nif gene expression, was cloned into a number of plasmid vectors to obtain high-level synthesis of nif $A$ product ( $\mathrm{NifA}$ ). When over-produced, $\mathrm{NifA}$ was very insoluble and it precipitated with the cell debris after cell lysis. Localization of $\beta$-galactosidase activity from a nif $A$-lac $Z$ translational fusion confirmed the insoluble nature of NifA. Analysis of two translational fusions in which the last six $\mathrm{C}$-terminal amino acids of $\mathrm{NifA}$ were deleted suggests that these residues are required for activity.

\section{INTRODUCTION}

The nitrogen fixation (nif) genes of Klebsiella pneumoniae comprise a cluster of at least 18 genes organized in eight operons. One of these operons consists of two genes, nifL and nif $A$, whose products are nif-specific regulatory proteins. The promoters of all the nif operons do not contain consensus -35 and -10 sequences characteristic of most prokarytic promoters but conform instead to a GG- $\mathrm{N}_{10}-\mathrm{GC}$ consensus located between -24 and -11 (Beynon et al., 1983). These promoters are all subject to positive control, and activation of transcription initiation from nif promoters requires the products of two genes, nif $A$ and $n t r A$, together with RNA polymerase core enzyme (Buchanan-Wollaston et al., 1981; Merrick, 1983). The ntrA product (NtrA) acts as a specific sigma factor (Hirschman et al., 1985; Hunt \& Magasanik, 1985; Austin et al., 1987) and the nif $A$ product (NifA) is a specific activator protein.

The method by which NifA activates transcription from the $-24,-11$ region is not known but recent studies have demonstrated that most nif promoters contain an upstream activator sequence (UAS) which significantly enhances activation of transcription (Buck et al., 1986, 1987). This UAS is characterized by a sequence TGT- $\mathrm{N}_{10}-\mathrm{ACA}$ typical of DNA-binding sites for regulatory proteins and it has been proposed that these sites may be binding sites for NifA (Buck et al., 1986, 1987). The nif $A$ gene of $K$. pneumoniae has been sequenced (Buikema et al., 1985; Drummond et al., 1986) and this has allowed prediction of the domain structure of the NifA protein and identification of a potential DNA-binding domain in the C-terminus of the protein (Drummond et al., 1986).

As a result of an increase in the levels of intracellular fixed nitrogen, or of an increase in the extracellular oxygen tension, NifA loses its ability to activate transcription; this has been attributed to inactivation of NifA by the nifL product (NifL). Hence NifL appears to act as a sensor to changes in the nitrogen or oxygen status of the cell and to modulate NifA activity accordingly (Hill et al., 1981; Merrick et al., 1982).

$\dagger$ Present address: Biology and Agriculture Division, Bhabha Atomic Research Centre, Trombay, Bombay 400085 , India.

Abbreviations: dNTP, deoxynucleoside triphosphate; X-gal, 5-bromo-4-chloro-3-indolyl $\beta$-D-galactoside. 
In order to study the molecular details of NifA function it is necessary to purify NifA and study its action in a cell-free system. In working towards this goal we have constructed a number of NifA-overproducing plasmids and nif $A-l a c Z$ fusions which have been used to examine various aspects of NifA function.

\section{METHODS}

Bacterial strains. These are listed in Table 1.

Cloning nif $A$ for over-production. The nif $A$ gene was cloned from plasmid pX901, which comprises a $2.9 \mathrm{~kb} S a / l$ fragment, carrying the $3^{\prime}$ end of nif $L$, the complete nif $A$ gene and the $5^{\prime}$ end of nifB, cloned in pEMBL8 $(+)(\mathrm{M}$. Drummond, personal communication) (Fig. 1). Most of nifL was removed by partial digestion with NruI and ligation with the 'filled' BamHI site of the vector so as to leave only 68 nucleotides at the 3 ' end of nifL. The resultant plasmid, pRT902, carries a $2.2 \mathrm{~kb}$ EcoRI-HindIII fragment which could then be cloned adjacent to a number of strong promoters in order to achieve high-level expression of NifA. Three expression vectors, pKK2233 (Pharmacia), pHL200 (Kröger \& Hobom, 1982) and pLc236 (Remaut et al., 1981) were used in order to obtain expression of nif $A$ from the tac, lac $U V 5$ and $\lambda p_{\mathrm{L}}$ promoters respectively. The resultant plasmids were designated pRT903 (tac), pRT201 (lacUV5) and pRT237 ( $\left.\lambda p_{\mathrm{L}}\right)$.

Construction of $p R T 22$ - a 'compatible' nifH-lacZ translational fusion. In order to provide a simple assay for NifA overproduction, a nifH-lac Z fusion plasmid, pWVC22 (Buck \& Cannon, 1987), was modified by opening the molecule at the PstI site in the bla gene, 'filling-in' the restriction site using Klenow polymerase in the presence of dNTPs and religating, thereby mutating the bla gene. The resultant plasmid pRT22 does not confer ampicillin or carbenicillin resistance $\left(\mathrm{Cb}^{r}\right)$ but retains the chloramphenicol resistance $\left(\mathrm{Cm}^{r}\right)$ marker of the parent plasmid. pRT22 is compatible with all three pBR322-based expression vectors used in these experiments and both the nif $A$ and nifH-lacZ plasmids could be independently selected using $\mathrm{Cb}^{r}$ and $\mathrm{Cm}^{r}$ respectively.

Translational fusions with nif $A$. Using the nucleotide sequence of the nif $A$ gene (Drummond et al., 1986) it was possible to construct both out-of-frame and in-frame translational fusions using vectors pNM481 and pNM480 (Minton, 1984) respectively. The restriction enzyme EcoRV cleaves nif $A$ between codons 518 and 519 (see Fig. 2) and therefore partial digestion of the $2.2 \mathrm{~kb} E c o \mathrm{RI}-H i n d I I I$ fragment from pRT903 allowed isolation of a $1.6 \mathrm{~kb}$ $E c o$ RI-EcoRV fragment in which seven codons at the $3^{\prime}$ end of $n i f A$ were deleted. This fragment was cloned into EcoRI-SmaI-cut pNM481 to give pRT482 in which nif $A$ was 'out-of-frame' with lac $Z$. The resultant fusion extends 17 codons beyond the EcoRV site in nif $A$ and then terminates (Fig. 2). This hybrid gene was placed under

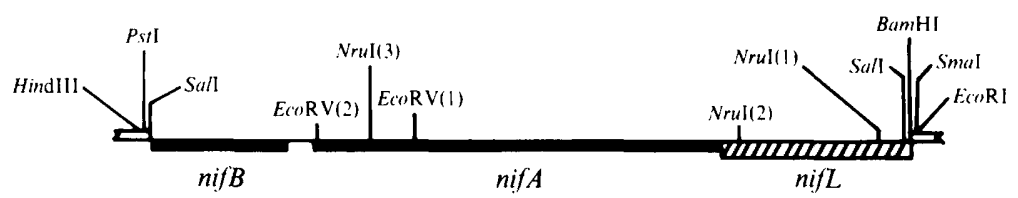

Fig. 1. A map of the nifA region of $K$. pneumoniae showing restriction endonuclease sites used in this study. The extent of nifL, nif $A$ and $n i f B$ in the $2.9 \mathrm{~kb}$ SalI fragment flanked by the restriction site nest of the vector pEMBL8(+) is shown. As described in Methods, the BamHI-NruI(2) segment was deleted in order to remove most of nif $L$ prior to construction of the transcriptional fusions (pRT903, pRT201 and pRT237). The EcoRI-EcoR (2) fragment from pRT903 was used to obtain the translational fusion in pRT482.

Table 1. List of strains

Strain

E. coli $\mathrm{K} 12$

71-18 $\Delta($ lac-pro $)$ supE thi $\left[\mathrm{F}^{\prime}\right.$ proAB lacI ${ }^{\mathrm{Q}}$ lacZ $\left.\Delta \mathrm{M} 15\right]$

MC1061 araD139 $\Delta($ ara-leu $) 7697$ lac $\Delta X 74 \mathrm{galU}_{\mathrm{galK}} \mathrm{hsr} \mathrm{hsm}^{+}$str A

M5219 M72 lacZam trpam Sm ${ }^{\mathrm{R}}(\lambda$ bio252 cl857 $\Delta \mathrm{H} 1)$

ET8894 rbs lacZ: :IS 1 gyrA hutC ${ }_{k} \Delta($ rha $g \ln A$ ntrBC $) 1703::$ Mucts62

ET8556 rbs lacZ::IS1 gyrA hutC $k_{k}$ ntrCl488 gyrA

5K thr leu thi resK $\bmod K^{+} \operatorname{ton} A$ supE $\lambda^{\mathrm{s}}$

$5 \mathrm{KR} \quad$ rec derivative of $5 \mathrm{~K}$ by $\mathrm{P} 1$ transduction from DB6659

K. pneumoniae M5al

UNF714 nifA2263 hisD2 recA56 sbl300::TnI0 rpsL4 hsdRI

UNF931 $\triangle$ lac2002 hisD2 recA56 sbl300::Tn10 hsdR1
Reference/source

J. Messing, University of Minnesota, St Paul, USA Casadaban \& Cohen (1980) Remaut et al. (1981) T. MacNeil, Merck, Sharp \& Dohme, Rahway, NJ, USA

This laboratory

Buchanan-Wollaston et al. (1981) This laboratory 
pNM481 linker

$><$

$\operatorname{lac} \mathbf{Z}^{\prime}$

$>$

pRT904 . . ATG GAT GGG GAT CCG TCG ACC TGC AGC CAA GCT TGC TCC CGT CGT TTT ACA ACG TCG TGA EcoRV/SmaI
nif $A^{\prime}><$
pNM480 linker
$><$
$\operatorname{lac} Z$

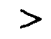

pRT905 . . A ATG GAT GGG CAT CCG TCG ACC TGC AGC CAA GCT TGC GAT CCC GTC - 1024 codons - TAA

\section{EcoRV/SmaI}

Fig. 2. Structure of nif $A-l a c Z$ translational fusions. At the $E c o R V-S m a I$ junction, the 518 th codon (GAT) of nif $A$ was joined through the cloning nest of pNM481 or pNM480 to the 8th codon (CCC) of lac $Z$. In the resultant plasmid pRT904, lac Z was out-of-frame, leading to the termination of nif $A$ at TGA after an extension of 17 codons. In pRT905 the linker region of pNM480 restored the reading frame of $l a c Z$.

control of the tac promoter by cloning a $4.7 \mathrm{~kb}$ EcoRI $-A$ haIII fragment from pRT 482 between the EcoRI and SmaI sites of pKK223-3 to construct pRT904. The fusion junction in pRT904 was confirmed by sequencing.

An in-frame translational fusion (pRT905) was constructed by cloning a 2 kb Sall fragment from pRT904 into pNM480, which contains two extra bases in the linker region (Fig. 2). The correct orientation for the Sall fragment was identified by selection of blue colonies on media containing X-gal.

Purification of nif $A$ gene product. The nif $A$ over-producing strain ET8894(pRT903) was grown to late-exponential phase in L-broth containing $200 \mu \mathrm{g}$ carbenicillin $\mathrm{ml}^{-1}$ and induced overnight in the presence of $0.2 \mathrm{mM}$-IPTG before harvest. The cell pellet was washed in buffer A ( $50 \mathrm{~mm}$-Tris pH 8.0, magnesium acetate $5 \mathrm{mM}, \mathrm{NaCl} 50 \mathrm{mM}$, 2-mercaptoethanol $2 \mathrm{mM}$, EDTA $0.1 \mathrm{mM}$ ), resuspended in the same buffer, using six times the pellet volume, and the cells were disrupted by sonication or French press. The suspension was centrifuged at $15000 \mathrm{~g}$ for $30 \mathrm{~min}$ to obtain a NifA-enriched pellet. The pellet was solubilized in buffer A containing $0 \cdot 2 \%$ SDS by stirring at room temperature in 500 times the pellet volume for $30 \mathrm{~min}$. Ammonium sulphate was added to the suspension to $30 \%$ saturation and the precipitated material was discarded. The proteins precipitated between 50 and $80 \%$ saturated ammonium sulphate were enriched in NifA, as followed by SDS-PAGE (see Fig. 5).

In vitro coupled transcription/translation. An S-30 extract was prepared from $E$. coli sțrain ET8556 and plasmidencoded gene products were labelled using the method of Collins (1979). The $\left.{ }^{35} S\right]$ methionine-labelled polypeptides were visualized by autoradiography after separation by SDS-PAGE and treatment of the acrylamide gel with Amplify (Amersham).

Other methods. All enzymes were obtained from commercial sources and used according to the manufacturers' instructions. Sequencing was done by dideoxy sequencing reactions using clones prepared in M13mp8 and $\mathrm{mpl} 1$. $\beta$-Galactosidase units were determined by the method of Putnam \& Koch (1975).

\section{RESULTS}

\section{Over-production of NifA}

All three plasmids, pRT903, pRT201 and pRT237, carrying transcriptional fusions of nif $A$ with tac, lac $U V 5$ and $\lambda p_{\mathrm{L}}$ promoters respectively, were able to activate the expression of $\beta$ galactosidase from the nif $H$ promoter in $\mathrm{pRT} 22$. Expression from the tac and lacUV5 promoters, unlike that from $\lambda p_{\mathrm{L}}$, was not tightly regulated (Table 2 ).

The amount of NifA synthesized from a single chromosomal nif $A$ gene or from nif $A$ expressed constitutively from pMC73A (Buchanan-Wollaston et al., 1981) was too low to be visualized by staining of whole-cell proteins separated by one-dimensional SDS-PAGE. However, all the three plasmids made in this study directed synthesis of a distinct protein band (see pRT903 in Fig. $3 a$ ) with an estimated molecular mass of $56000 \mathrm{Da}$, which agrees well with the molecular mass of $58632 \mathrm{Da}$ calculated from the nifA DNA sequence (Drummond et al., 1986). The position of the presumptive NifA band was confirmed by comparison with the mobility of $\left[{ }^{35}\right.$ S]methionine-labelled NifA synthesized from pRT903 in a cell-free coupled transcription/ translation system (Fig. $3 b$ ). 


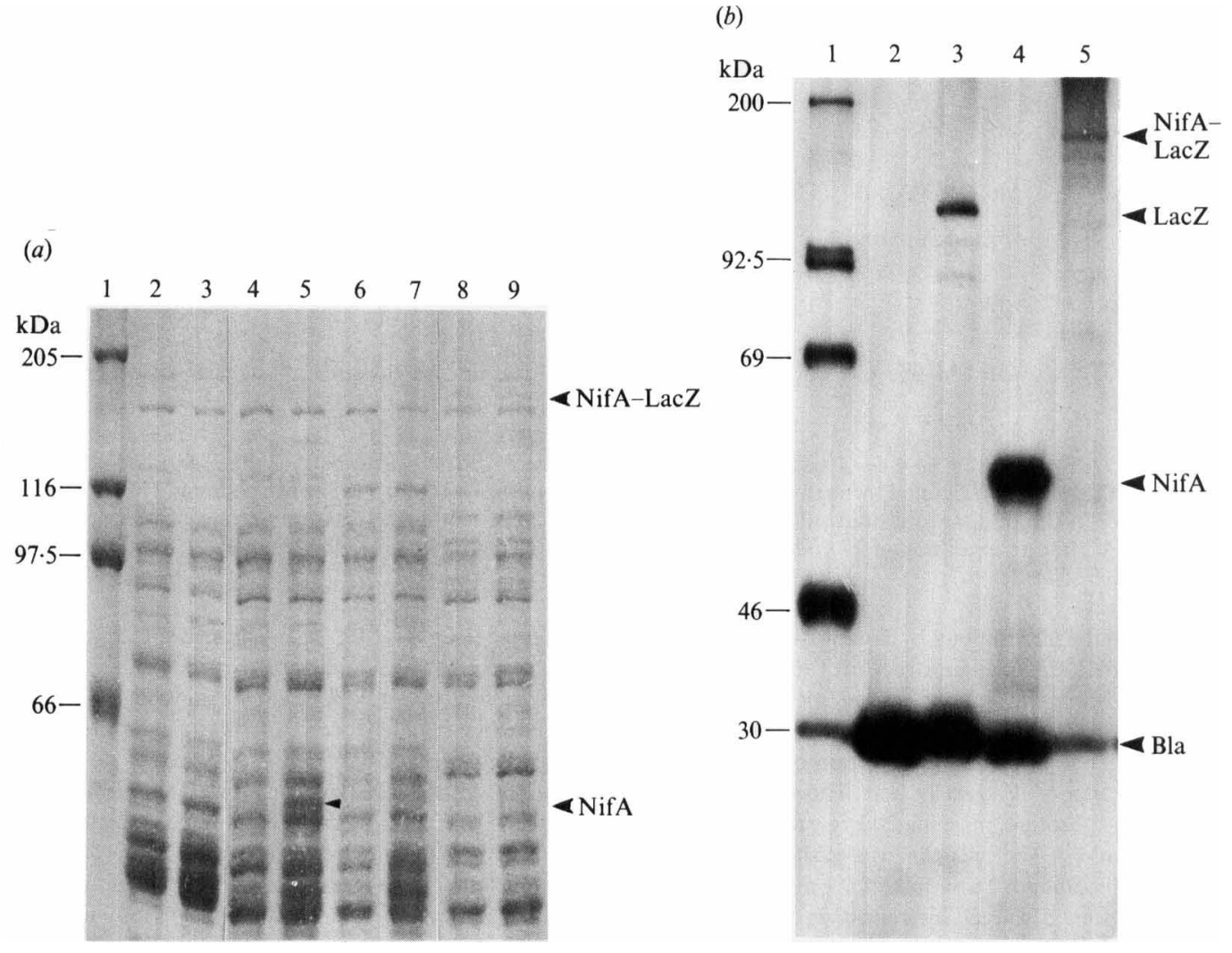

Fig. 3. Expression of $n i f A$ and the nif $A-l a c Z$ in-frame fusion from the tac promoter. (a) SDS-PAGE of cell-free extracts from 5KR(pKK223-3) (lanes 2 and 3), 5KR(pRT903) (lanes 4 and 5), 5KR(pMC73A) (lanes 6 and 7) and UNF931(pRT905) (lanes 8 and 9), $2 \mathrm{~h}$ (lanes 2, 4, 6 and 8) and overnight (lanes 3, 5, 7 and 9) after induction with IPTG. The positions of NifA and hybrid NifA- $\beta$-galactosidase are marked by arrows. Lane 1 contains molecular mass standards. (b) Autoradiograms of SDS-PAGE of in vitro transcription/translation products from pBR322 (lane 2) pRT903 (lane 4) and pRT905 (lane 5). Lane 3 shows the translation products of pRD572 (Hawkes et al., 1985), which contains genes for $\beta$-lactamase and $\beta$-galactosidase. Lane 1 contains molecular mass standards.

Table 2. Activation of nifH promoter on $p R T 22$ (pnifH-lacZ) by various nif $A$ plasmids

Cells were grown in LB to exponential phase at $28^{\circ} \mathrm{C}$ and induced with IPTG $(0.2 \mathrm{mM})$ or temperature $\left(42^{\circ} \mathrm{C}\right.$ for $15 \mathrm{~min}$ ). $\beta$-Galactosidase activity is expressed as nmol ONPG hydrolysed per $\mathrm{ml}$ cells $\left(O D_{600}=1\right) \mathrm{min}^{-1}$. Induced cells were assayed $2 \mathrm{~h}$ after induction. ND, Not done.

Strain

71-18(pRT22)

71-18(pRT22) (pRT903)

71-18(pRT22) (pRT904)

MC1061(pRT22) (pRT201)

M5219(pRT22) (pRT237)
Genotype of nif $A$ plasmid

$$
\begin{gathered}
(\mathrm{ptac}-n i f A) \\
\left(\mathrm{ptac}-n i f A^{\prime}\right) \\
(\mathrm{plac} U V 5-n i f A) \\
\left(\lambda p_{\mathrm{L}}-n i f A\right)
\end{gathered}
$$

Promoter induction

$$
\begin{aligned}
& \text { - IPTG } \\
& + \text { IPTG } \\
& \text { - IPTG } \\
& + \text { IPTG } \\
& \text { - IPTG } \\
& + \text { IPTG } \\
& \text { - IPTG } \\
& + \text { IPTG } \\
& 28^{\circ} \mathrm{C} \\
& 42^{\circ} \mathrm{C}
\end{aligned}
$$

$\beta$-Galactosidase
ND

4978

7714

ND

12046

15314

195 


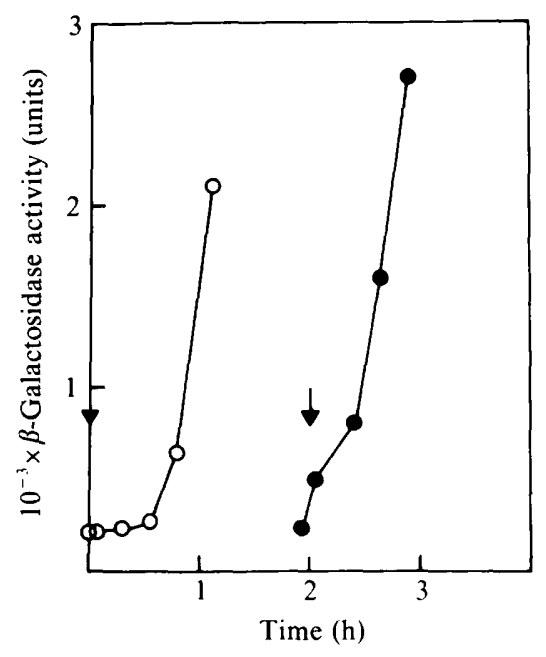

Fig. 4

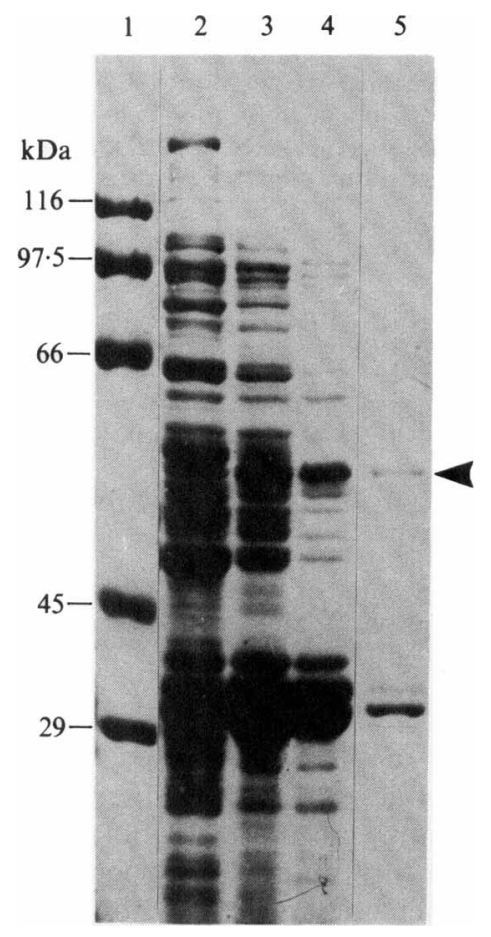

Fig. 5

Fig. 4. Reversible temperature-sensitivity of NifA function. The time course of appearance of $\beta$ galactosidase activity is shown for M5219(pRT237)(pRT22). After induction of $\lambda p_{\mathrm{L}}$ at $45^{\circ} \mathrm{C}$ for $15 \mathrm{~min}$, the cultures were incubated at $28^{\circ} \mathrm{C}$ immediately $(O)$ or $2 \mathrm{~h}$ after incubation at $40^{\circ} \mathrm{C}(O)$. Samples were taken to estimate the enzyme activity at various intervals (Putnam \& Koch, 1975). The time of transfer to $28^{\circ} \mathrm{C}$ is indicated by vertical arrows.

Fig. 5. Purification of NifA from ET8894(pRT903): SDS-PAGE of denatured samples. Lane 1, molecular mass standards; lane 2, cell-free extract; lane 3, pellet; lane 4, pellet after a wash with buffer A; lane 5, partially purified NifA preparation. The position of NifA is indicated by the arrow.

\section{Reversibility of temperature-inactivation of NifA function}

$K$. pneumoniae NifA does not activate transcription from nif promoters at temperatures above $37^{\circ} \mathrm{C}$ (Buchanan-Wollaston et al., 1981; Brooks et al., 1984). The reversibility of this temperature-sensitivity was studied by comparing the kinetics of appearance of $\beta$-galactosidase activity from the nifH-lac Z fusion in pRT22 after different periods of heat induction of $\lambda p_{\mathrm{L}}-$ nif $A$ in pRT237. Duplicate exponential-phase cultures of $E$. coli strain M5219 carrying pRT237 and pRT22 were incubated at $45^{\circ} \mathrm{C}$ for $15 \mathrm{~min}$ in order to induce NifA synthesis from pRT237 and incubation was then continued at either $28^{\circ} \mathrm{C}$ or $40^{\circ} \mathrm{C}$. In the $28^{\circ} \mathrm{C}$ culture induction of NifA synthesis was followed by an increase in nifH-lac Z expression after a lag of about $20 \mathrm{~min}$ (Fig. 4). However in the $40^{\circ} \mathrm{C}$ culture no significant increase in nifH-lac $Z$ expression was observed for $2 \mathrm{~h}$. After $2 \mathrm{~h}$ at $40^{\circ} \mathrm{C}$ this culture was shifted to $28^{\circ} \mathrm{C}$ and an immediate increase in nifHlac $Z$ expression was observed (Fig. 4).

\section{Purification of NifA}

Initial attempts to purify NifA showed that it migrated on one-dimensional SDS-PAGE very close to certain other proteins including glutamine synthetase (GS) and $\mathrm{NtrC}$, as expected from previous estimates of the molecular masses of these proteins ( NtrC $52.3 \mathrm{kDa}$, NifA $58.6 \mathrm{kDa}$, GS $51.8 \mathrm{kDa}$ ) (Espin et al., 1982; Merrick, 1983). Consequently strain ET8894(pRT903), which has a deletion of the $\operatorname{gln} A \operatorname{ntr} B C$ region, was used for all subsequent experiments. The NifA 


\section{Table 3. Solubilization of hybrid NifA- $\beta$-galactosidase protein}

A $2 \mathrm{ml}$ culture of ET8894(pRT905) induced overnight with IPTG was sonicated in buffer A and centrifuged in a microfuge for $15 \mathrm{~min}$. The pellet was resuspended in $20 \mu \mathrm{l}$ buffer $\mathrm{A}$ and $10 \mu \mathrm{l}$ of this suspension was incubated in $50 \mu \mathrm{l}$ buffer $A$ made up to give the treatments indicated. After 15 min at room temperature, the suspension was centrifuged and $\beta$-galactosidase activity estimated in the two fractions.

Treatment
Control
$50 \%$ glycerol
$1 \%$ Triton X-100
$2 \mathrm{M}-\mathrm{NaCl}$
$25 \%$ ethylene glycol
pH 6.5
pH $9 \cdot 0$
$0.2 \%$ SDS

$\begin{array}{cc}\text { Supernatant } & \text { Pellet } \\ 0.13 & 1.81 \\ 0.22 & 2.16 \\ 0.06 & 1.7 \\ 0.22 & 2.0 \\ 0.11 & 1.8 \\ 0.23 & 1.96 \\ 0.2 & 1.77 \\ 1.06 & 0.69\end{array}$

* Expressed as $A_{420}$ per assay for the colour developed after $15 \mathrm{~min}$ incubation at $28^{\circ} \mathrm{C}$.

synthesized in ET8894(pRT903) sedimented with the pellet obtained on centrifuging the cell-free extract at $15000 \mathrm{~g}$ (Fig. 5). This protein co-migrated in SDS-PAGE with the ${ }^{35}$ S]methionine-labelled NifA obtained from the in vitro transcription/translation of pRT903 and was absent from the pellet obtained from cells containing vector alone (data not shown).

Co-sedimentation of NifA with the pellet of cellular debris was further substantiated by the behaviour of the hybrid NifA- $\beta$-galactosidase protein synthesized from the in-frame fusion in pRT905. $\beta$-Galactosidase is a soluble enzyme and more than $90 \%$ of the enzyme activity was present in the supernatant of cell extracts from strain $5 \mathrm{~K}$ (pRT903), which carries a chromosomal lac $Z$ together with a nif $A$ plasmid, pRT903. However, in comparable cells containing a nif $A$-lac $Z$ in-frame translational fusion (pRT905), nearly $90 \%$ of $\beta$-galactosidase activity sedimented with the pellet of cellular debris (data not shown). Therefore the tendency of $\mathrm{Nif} A$ to sediment was retained in the hybrid NifA- $\beta$-galactosidase protein. The $\beta$-galactosidase activity in the hybrid protein served as a convenient marker to examine the solubilization of NifA from the pellet.

Inclusion of $50 \%(\mathrm{v} / \mathrm{v})$ glycerol, $1 \%(\mathrm{v} / \mathrm{v})$ Triton X-100, $2 \mathrm{M}-\mathrm{NaCl}$ or $25 \%(\mathrm{v} / \mathrm{v})$ ethylene glycol in buffer $\mathrm{A}$, or adjustment of the $\mathrm{pH}$ to 6.5 or 9.0 , failed to solubilize any appreciable amount of $\beta$-galactosidase activity from the pellet of ET8894(pRT905). However, SDS at $0.05 \%$ released nearly $25 \%$ of the $\beta$-galactosidase activity from the pellet and $0.2 \%$ SDS released nearly $60 \%$ (Table 3). Higher levels of SDS inactivated the $\beta$-galactosidase activity of the hybrid protein and even $0.2 \%$ SDS made the protein thermolabile. The fusion protein was completely inactivated by a 15 min preincubation in the SDS buffer at $37^{\circ} \mathrm{C}$, whereas in the absence of SDS, the fusion protein, like the native enzyme, was fairly stable (data not shown).

The ability of SDS to solubilize the native NifA protein partially from the pellet was utilized to develop a simple procedure for its purification. The pellet was solubilized by stirring in a 500 fold excess of buffer A containing $0.2 \%$ SDS. Ammonium sulphate precipitation $(50-80 \%$ fraction) of the solubilized pellet gave a highly enriched NifA preparation that contained one major and a few minor contaminating proteins (Fig. 5). Resolubilization of this fraction required continued presence of SDS.

\section{Nif $A$ function requires $C$-terminal residues}

The translational fusion in pRT905 made a hybrid protein of approximately $170 \mathrm{kDa}$ that retained catalytic activity of $\beta$-galactosidase. However, the chimaeric NifA-LacZ failed to activate the nifH promoter in pRT22 or to complement the nif $A 2263$ mutation in K. pneumoniae UNF714 (data not shown), suggesting that the hybrid protein was not functionally active as NifA. The out-of-frame translational fusion in pRT904 is predicted to produce a hybrid protein 
which contains the native primary sequence of NifA with the exception of six C-terminal amino acids which are replaced by a new sequence of 17 amino acids joined to Asp518 of NifA (Fig. 2). In a cell-free transcription/translation system pRT904 expressed a polypeptide that migrated to the position of NifA on SDS-PAGE. However, pRT904 failed to activate the nifH promoter in vivo (Table 2), indicating that the last six amino acids of NifA are important structurally or functionally for its activity.

\section{DISCUSSION}

We have described the construction of a number of plasmids which allow over-production of NifA, together with a rapid method for partial purification of the protein. However, the sedimentation of NifA in the $15000 \mathrm{~g}$ pellet creates difficulties in its purification, and in the absence of an in vitro assay it is not presently possible to monitor NifA activity.

Both the NifA-LacZ hybrid encoded by pRT905 and the hybrid NifA from pRT904 lack the last six residues of NifA and therefore the proposed C-terminal helix-turn-helix (HTH) motif may be disrupted. The failure of both these proteins to activate transcription from the nifH promoter therefore supports the suggestion (Drummond et al., 1986) that the HTH motif is required for DNA-binding by NifA. Our demonstration of the reversibility of temperatureinactivation of NifA is consistent with the results of Brooks et al. (1984). The temperaturesensitive component responsible for failure of nif expression at temperatures above $37^{\circ} \mathrm{C}$ may be either the NifA protein itself, the interaction of NifA with nif promoters or possibly the thermolability of the nifH-lacZ mRNA (Collins et al. 1986). In the light of the proposed role of DNA looping in activation of transcription by NifA (Buck et al., 1987) it is possible that the temperature-sensitive component is indeed the formation of the DNA conformation necessary for activation rather than the NifA protein per se.

The NifA protein is functionally very similar to the homologous activator protein $\mathrm{NtrC}$ and these proteins can substitute for one another in activation of NtrA-dependent promoters such as pnifLA or pglnA (Merrick, 1983; Ow \& Ausubel, 1983). However, NtrC is a soluble protein and unlike NifA it does not precipitate when overproduced (Hawkes et al., 1985). Comparison of the predicted amino acid sequences of NifA and NtrC led Drummond et al. (1986) to propose a three-domain structure for the two proteins, comprising a 120-180 amino acid N-terminal domain followed by a short linker sequence, a central domain of about 240 amino acids and a Cterminal domain of about 70 residues. Whilst the central domains of NifA and NtrC, which may be involved in interaction with RNA polymerase, are highly homologous, both the N-terminal and $\mathrm{C}$-terminal domains are distinctly different. The role of the $\mathrm{N}$-terminus is unknowr but it has been proposed that this domain is involved in interaction with the respective partner protein (Drummond et al., 1986; Drummond \& Wootton, 1987; Ronson et al., 1987).

The C-terminus in both NifA and NtrC contains a potential HTH motif which is distinctly different in the two proteins, and the second helix of this motif is probably responsible for the DNA-binding specificities of the two proteins (Drummond et al., 1986). As the hybrid proteins synthesized from both pRT904 and pRT905 had a modified C-terminus but retained the insolubility characteristics of wild-type NifA these results suggest that the $\mathrm{N}$-terminal domain of NifA might be the region responsible for the differences in solubility properties between NifA and $\mathrm{NtrC}$.

We thank R. A. Dixon, S. Austin and B. E. Smith for helpful comments on the manuscript and Beryl Scutt for typing it. R. Tuli was supported by an Overseas Fellowship from the National Biotechnology Board of India.

\section{REFERENCES}

Austin, S., Henderson, N. \& DiXon, R. (1987). Requirements for transcriptional activation in vitro of the nitrogen regulated $g \ln A$ and $n i f L A$ promoters from Klebsiella pneumoniae: dependence on activator concentration. Molecular Microbiology 1, 92-100.
Beynon, J., Cannon, M., Buchanan-Wollaston, V. \& CANnon, F. (1983). The nif promoters of Klebsiella pneumoniae have a characteristic primary structure. Cell 44, 665-671.

Brooks, S. J., Collins, J. J. \& BRILl, W. J. (1984). 
Repression of nitrogen fixation in Klebsiella pneumoniae at high temperature. Journal of Bacteriology 157, 460-464.

Buchanan-Wollaston, V., Cannon, M. C., Beynon, J. L. \& CanNon, F. C. (1981). Role of the nif $A$ gene product in the regulation of nif expression in Klebsiella pneumoniae. Nature, London 294, 776-778.

Buck, M. \& CANNON, W. (1987). Frameshifts close to the Klebsiella pneumoniae nifH promoter prevent multicopy inhibition by hybrid nifH plasmids. Molecular and General Genetics 207, 492-498.

Buck, M., Miller, S., Drummond, M. \& Dixon, R. (1986). Upstream activator sequences are present in the promoters of nitrogen fixation genes. Nature, London 320, 374-378.

Buck, M., Cannon, W. \& Woodcock, J. (1987). Transcriptional activation of the Klebsiella pneumoniae nitrogenase promoter may involve DNA loop formation. Molecular Microbiology 1, 243-249.

Buikema, W. J., Szeto, W. W., LeMLey, P. V., ORMEJohnson, W. H. \& AusubeL, F. M. (1985). Nitrogen fixation specific regulatory genes of Klebsiella pneumoniae and Rhizobium meliloti share homology with the general nitrogen regulatory gene ntrC of $K$. pneumoniae. Nucleic Acids Research 12, 4539-4555.

Casadaban, M. J. \& Cohen, S. N. (1980). Analysis of gene control signals by DNA fusion and cloning in Escherichia coli. Journal of Molecular Biology 138, 179-207.

Collins, J. (1979). Cell free synthesis of proteins coding for mobilisation functions of ColEl and transposition functions of Tn3. Gene 6, 29-42.

Collins, J. J., Roberts, G. P. \& Brill, W. J. (1986). Posttranscriptional control of Klebsiella pneumoniae nif mRNA stability by the nifL product. Journal of Bacteriology 168, 173-178.

DRUMMOND, M. \& WoOTTON, J. (1987). Sequence of nifL from Klebsiella pneumoniae: mode of action and relationship to two families of regulatory proteins. Molecular Microbiology 1, 37-44.

DRummond, M., WhitTy, P. \& Wootton, J. (1986). Sequence and domain relationships of $n \operatorname{tr} C$ and nif $A$ from Klebsiella pneumoniae: homologies to other regulatory proteins. EMBO Journal 5, 441-447.

Espin, G., Alvarez-Morales, A., Cannon, F., DiXoN, R. \& MERrick, M. (1982). Cloning of the $\operatorname{g} \ln A, n \operatorname{tr} B$ and $n t r C$ genes of Klebsiella pneumoniae and studies on their role in regulation of the nitrogen fixation (nif) gene cluster. Molecular and General Genetics 186, 518-524.

HaWkes, T., Merrick, M. \& Dixon, R. (1985).
Interaction of purified NtrC protein with nitrogen regulated promoters from Klebsiella pneumoniae. Molecular and General Genetics 201, 492-498.

Hill, S., Kennedy, C., Kavanagh, E., Goldberg, R. B. \& HANAU, R. (1981). Nitrogen fixation gene (nifL) involved in oxygen regulation of nitrogenase synthesis in Klebsiella pneumoniae. Nature, London 290, 424-426.

Hirschman, J., Wong, P. K., Sei, K., Keener, J. \& KUSTU, S. (1985). Products of nitrogen regulatory genes $n \operatorname{tr} A$ and $n \operatorname{tr} C$ of enteric bacteria activate $g \ln A$ transcription in vitro: evidence that the $n t r A$ product is a sigma factor. Proceedings of the National Academy of Sciences of the United States of America 82, 7525-7529.

Hunt, T. P. \& Magasanik, B. (1985). Transcription of glnA by purified Escherichia coli components: core RNA polymerase and the products of $g \ln F, g \ln G$ and $g \ln L$. Proceedings of the National Academy of Sciences of the United States of America 82, 8453-8457.

KRÖGER, M. \& Новом, G. (1982). Structural analysis of insertion sequence IS5. Nature, London 297, 159 162.

MERRICK, M. (1983). Nitrogen control of the nif regulon in Klebsiella pneumoniae: involvement of the $n \operatorname{tr} A$ gene and analogies between $n t r C$ and nif $A$. EMBO Journal 2, 39-44.

Merrick, M., Hill, S., Hennecke, H., Hahn, M., DIXON, R. \& KENNEDY, C. (1982). Repressor properties of the nifL gene product in Klebsiella pneumoniae. Molecular and General Genetics 185, 7581.

Minton, N. P. (1984). Improved plasmid vectors for the isolation of translational lac gene fusions. Gene 31, 269-273.

Ow, D. W. \& Ausubel, F. M. (1983). The nifA gene which regulates the Klebsiella pneumoniae nif gene cluster can substitute for the nitrogen regulatory gene $\operatorname{gln} G$ (ntrC). Nature, London 301, 307-313.

Putnam, S. L. \& КосH, A. L. (1975). Complications in the simplest cellular enzyme assay: lysis of Escherichia coli for the assay of $\beta$-galactosidase. Analytical Biochemistry 63, 350-360.

Remaut, E., Stanssens, P. \& Fiers, W. (1981). Plasmid vectors for high-efficiency expression controlled by the $p_{\mathrm{L}}$ promoter of coliphage lambda. Gene 15, 81-93.

Ronson, C. W., Nixon, B. T. \& Ausubel, F. M. (1987). Conserved domains in bacterial regulatory proteins that respond to environmental stimuli. Cell 49, 579-581. 